DOI: https://doi.org/10.34069/AI/2022.49.01.8

How to Cite:

Shkola, G., Taranik-Tkachuk, K., Pashynska, L., Kozlovska, L., \& Krasnopolska, N. (2022). Dispute on the Internet: the format of discourse, linguistic technologies, modern language tactics. Amazonia Investiga, 11(49), 69-75.

https://doi.org/10.34069/AI/2022.49.01.8

\title{
Dispute on the Internet: the format of discourse, linguistic technologies, modern language tactics
}

\section{Диспут в інтернеті: формат дискурсу, лінгвістичні технології, сучасні мовні тактики}

Received: November 20, 2021

Accepted: December 28, 2021

Written by:

Galyna Shkola ${ }^{26}$

https://orcid.org/0000-0001-7292-899X

Kateryna Taranik-Tkachuk ${ }^{27}$

https://orcid.org/0000-0003-0158-3124

Liudmyla Pashynska ${ }^{28}$

https://orcid.org/0000-0001-5764-1747

Larysa Kozlovska $^{29}$

https://orcid.org/0000-0002-0523-9913

Nataliia Krasnopolska ${ }^{30}$

https://orcid.org/0000-0003-3524-1704

\begin{abstract}
The concept of discourse is fundamental to modern linguistics. Discourse is a connecting link for all linguistic research, and modern ideas about discourse, without exaggeration, reflect the process of formation of linguistic science. The purpose of this work is to analyze the linguistic and stylistic features of the dispute on the Internet, namely: the format of discourse, linguistic technologies, and modern language tactics. The subject of the study is the debate on the Internet as a way to find out the positions of the participants in the discussion. During the study, a number of general scientific methods were used: the method of analogy, the method of generalization, the method of observation, the method of comparison, the method of experiment, the method of analysis, and the historical method. As a result of the research, the format of discourse, linguistic technologies, and modern language tactics of debate on the Internet were analyzed. Thus, it is emphasized that in the debate on the Internet, a combination of verbal and nonverbal components of the message realizes such an important feature of media discourse as multimedia. Non-verbal means of communication
\end{abstract}

\footnotetext{
${ }^{26}$ Candidate of Philological Sciences, Associate Professor of the Department of Ukrainian Philology and Slavic Studies, Kyiv National Linguistic University, Ukraine.

${ }^{27}$ Candidate of Pedagogical Sciences, Associate Professor, Department of Ukrainian Philology and Slavic Studies, Kyiv National Linguistic University, Kyiv, Ukraine.

${ }^{28}$ Candidate of Philological Sciences, Associate Professor of the Department of Ukrainian Philology and Slavic Studies, Kyiv National Linguistic University, Ukraine.

${ }^{29} \mathrm{PhD}$ in Philology, Associate Professor, Head of the Department of the Business Linguistics, Kyiv National Economic University named after Vadym Hetman, Ukraine.

${ }^{30} \mathrm{PhD}$ in Philology, Associate Professor of the of the Department of the Business Linguistics, Kyiv National Economic University named after Vadym Hetman, Ukraine.
} 
become a kind of background for the message, which thus receives additional expressiveemotional-evaluative overtones, which helps to put in the mind of the recipient a particular idea. In addition, the extreme pragmatism of modern man creates new challenges for its information. Today, to enhance the "presence effect", it is necessary to create the illusion of a new reality, an integral part of which is Internet discourse.

Keywords: debate, discourse, linguistic technologies, language tactics, linguistic and stylistic feature, Internet discourse.

\section{Introduction}

In modern conditions of the development of public relations, the Internet has become a powerful means of communication and a way of forming public opinion. It is thanks to the Internet that society is influenced, various stereotypes about politics, culture, economics, etc. are formed. Thus, the formation of the consciousness of the modern individual is influenced by several factors, among which discourses and disputes play an important role. with human speech activity, can not do without expression, whether oral or written.

Discourse and debate are the focus of many sciences: linguistics, philosophy, psychology, communication theory, etc. The transition to the paradigm of dispute and discourse can be considered a natural development of linguistic thought. More and more modern media outlets are accessing the Internet, combining aspects of mass periodicals and inclusion in the global information network. The functional orientation of discourse involves the implementation of its three main strategies: to attract attention, inform and influence the audience. These strategies determine the leading features of discourse on the Internet, such as the alternation and contrast of standardized and expressive means, the social nature of communication, communicative general significance and accessibility, and multimedia. In general, close to the purpose of the discussion is a dispute, which is a public debate on a scientific or social topic, thinking about one idea, discussing it. The dispute implies freedom, freedom, sincerity of the participants' statements. They are not grouped.

Thus, in today's society, where the main driving force is information, the key discourse that implements the movement of social thought and forms a conceptual picture of the human world як мультимодусніть. Зокрема, невербальні засоби комунікації стають своєрідним фоном для повідомлення, яке завдяки цьому отримує додаткові експресивно-емоційно-оцінні обертони, що допомагає закласти у свідомість реципієнта певну ідею. Крім того, надзвичайна прагматичність сучасної людини створює нові виклики для ii iнформування. Сьогодні задля посилення «ефекту присутності» необхідно створювати ілюзію нової реальності, невід'ємною складовою якої $є$ саме інтернетдискурс.

Ключові слова: диспут, дискурс, лінгвістичні технології, мовні тактики, мовно-стилістична особливість, дискурс Інтернет.

has become a dispute on the Internet. Given the popularity of the Internet, the interest of linguists in this phenomenon is becoming apparent.

The terms "computer discourse" and "electronic discourse" are similar in meaning, as they imply communication via computer. Internet discourse differs from other types of discourse by specific principles and rules of structural organization and is characterized by genre diversity. Given the popularity of the Internet and the transition to more and more communication practices, it is safe to say, that linguistic intelligence in the field of Internet communication will increase in direct proportion to this process and will be able to fill existing gaps and shed light on controversial issues related to the peculiarities of communication on the Internet.

Given the significance of this issue, it is necessary to pay special attention to the linguistic and stylistic features of the dispute, differences in its formats, linguistic technologies, format, and tactics to achieve the desired result.

\section{Theoretical Framework or Literature Review}

Linguistic and stylistic features of the dispute on the Internet were studied as domestic scholars, but a comprehensive analysis of the dispute was not conducted.

Among the scholars who dispute and discourse issues are: Perhach and Smirnova (2019), Anderson (2020), Ruda (2021), Kozhemyakin (2016), Aleksandrova (2003), Akhrenova (2009), Volodina (2005), Galichkina (2001), Husar (2004), Dobrosklonskaya (2005), Zheltukhina (2003), Zavgordnya (2003), Ilchenko (2003), Kalmykov (2005), Kibrik 


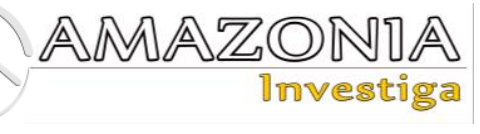

(2009), Kozhemyakin (2010), Pastukhov (2008), and Khalyapina (2005).

Aleksandrova (2003) studied the language of the media in the context of the collective space of society. According to Aleksandrova (2003), the media is a discourse, because they are dynamic, modern, and perceived by participants in communication in the context of current events. Akhrenova (2009), studied Internet discourse as a global intercultural phenomenon and its linguistic design.

According to Volodina (2005), the media can be seen as a form of "social dialogue". Galichkina (2001) focused on the specifics of computer discourse in English and Russian. The scholar defines computer discourse as a multi-genre functional variety of public dialogic and monologue speech that has emerged as a result of interpersonal computer communication. The subject of Husar's study (2004) was the ingvocognitive and communicative-pragmatic aspects of private newspaper advertisements. Meanwhile, Dobrosklonska (2005) in her work identified the role of the media in the dynamics of language processes.

Perhach and Smirnova (2019) devoted their work to define the concept of manipulation as a method of influencing the reader's consciousness, behavior, emotional and psychological state. The work aims to identify the goals of manipulative influence and the essential features of its use in modern print media. The study was based on a selection of articles from various Ukrainian and foreignlanguage publications. The authors believe that to determine the syntactic, stylistic, morphological, lexical, and semantic means of linguistic implementation of manipulation had to resort to the method of content analysis.

Morevoer, Ilchenko (2003) examined the expression of the name in the media in more detail. Kalmykov (2005) conducted a large-scale study of online journalism. The variety of parameters for the classification of discourses was the subject of Kibrik (2009). Also, Kozhemyakin (2010) analyzed mass communication and discourse methodology through a variety of research methods and dispute technologies.

Pastukhov (2008) considered the features of media texts, in turn, Khalyapina (2005) explored the features of discourses in foreign languages. Peculiarities of Internet media discourse were analyzed by Shevlyakova (2013), using materials from English-language online magazines for teenagers.

Though a large number of works on the peculiarities of dispute and discourse, the topic of linguistic and stylistic features of dispute on the Internet remains incompletely studied; in the context of the above, this issue needs to be studied.

\section{Methodology}

During the writing of the article, such scientific methods were used as a method of analogy, method of generalization, method of observation, method of comparison, method of experiment, method of analysis, historical method.

Thus, the method of observation created a general description of debate and discourse on the Internet, analyzed trends in media discourse and political debate, which later allowed us to conclude linguistic technologies and modern language tactics of discourse on the Internet.

The analysis method was used to study the trends in the development of the dispute and found that despite the spread of the dispute on the Internet, the characteristics of the dispute remain the same as during the media dispute outside the Internet. Also, the theoretical analysis of "debate" and "discourse" covered the basic concepts of discourse, and, along with the text and concept, allowed to consider the genre in its discursive function of mediator between individual and society, which provides certain roles of author and reader of the information on the Internet.

Along with the method of analysis, the method of synthesis is used, which consisted in this study in the combination of individual aspects of the study into a single whole. In particular, based on the use of certain formats of discourse, linguistic technologies, and modern language tactics, their role in the formation of communication on the Internet was highlighted. Also, it should be noted that the use of such a method as synthesis, at different stages of the study acquainted with the general features of the object under study and helped to understand its essence.

The method of comparison was used to highlight the features of discourse and debate in different conditions and environments, which in turn allowed to make generalizations about the impact of language tactics on the outcome.

Moreover, the generalization method helped to determine the linguistic and stylistic features of 
the dispute on the Internet and to draw conclusions about the relationship between tactics, strategy, and form of dispute. Thanks to the method of generalization, it was concluded that the communication process should be addressed as the unity of verbal and nonverbal components of communication, taking into account the influence of social and personal characteristics of the individual on his communicative behavior, including corporate discourse.

The use of the historical method made it possible to study the object of study in terms of features of development, which significantly enriches scientific research, testifies to the reliability of its results and conclusions, confirms scientific objectivity.

The method of modeling was expediently used in the formation of linguistic technologies and tactics of debate on the Internet. Thus, modeling different situations with their further usage in practice, it is more effective to pre-analyze the theoretical aspects, international experience, and model possible developments.

The method of analogy made it possible to establish the relationship of equivalence between the two systems under consideration on some grounds. Disputes on the Internet and beyond have become such systems.

In addition, such a method as an experiment was used. This method allowed us to predict the next stages of the transformation of the dispute on the Internet, given the current stage of development of public relations and technological progress.

\section{Results and Discussion}

Before analyzing the linguistic and stylistic features of the dispute on the Internet, it is essential to provide a definition of discourse and dispute.

In general, the term "discourse" was first used by the American scholar Harris in the theory of text linguistics in 1952 (Kalmykov, 2005).

At present, there is no single and generally accepted definition of the term "discourse", which can be explained by the wide popularity of this term, as well as the fact that it is the subject of interdisciplinary research.

On the one hand, discourse is related to the pragmatic situation necessary to determine the coherence of discourse, its communicative adequacy, and interpretation, and on the other hand - with the mental processes of communication (psychological, sociocultural, ethnographic principles and strategies for generating and understanding speech in specific conditions). Discourse develops within a specific situation, and discourse analysis provides an understanding of human interaction aimed at achieving certain goals, with communicators interpreting each other's speech and actions. Thus, the discursive analysis takes into account extralinguistic factors and this expands the boundaries of interpretation.

The large number of discourse typologies that exist today is, on the one hand, a consequence of the fact that not all typologies have clear classification criteria and sufficient empirical material, and on the other - since each area of human activity can generate its type discourse. Moreover, the typology of discourse is always historically determined and in each case is chosen by the researcher to solve specific problems. This suggests that an exhaustive classification of types of discourse is hardly possible or appropriate. However, attempts to create a universal classification of types of discourse do not stop. Today, the leading criteria for distinguishing types of discourse are those that are related to the categories of discourse and can be distinguished in terms of formal, functional, substantive criteria. Thus, the whole general discourse can be logically divided by one or another criterion.

"Computer discourse" is defined as a set of texts that are united by a common theme related to modern computer and information technology. Accordingly, computer discourse should be understood as communication mediated by electronic means of communication. And the main feature of computer communication is the communication of communicators in cyberspace. Computer-assisted communication can take place on the local, national or global Internet.

Network communication is distinguished according to the mode of interactivity (online, offline), the direction of communication (monologue, dialogue, polylogy), the degree of openness and accessibility (open, private).

A new environment of communication has been formed on the Internet, which includes oral and written speech - the electronic environment. To implement computer discourse, it is necessary to have a technical tool (personal computer), extralinguistic factors (spatial, temporal distance, belonging to a certain social stratum, etc.), 


\section{AMAZONIA \\ Trvestiga}

familiarity with specific computer vocabulary that serves as a means of unity and selfexpression of communicators.

There are the following signs of dispute:

1) electronic communication signal;

2) virtuality;

3) spatial and temporal distance;

4) mediation by technical means;

5) combination of letter, image-visual, and image-auditory components;

6) status equality of communicators;

7) the use of "smilies" to convey feelings, emotions;

8) combining different types of discourse, and;

9) observance of computer ethics (netiquette), etc.

Computer communication has become part of the multidimensional communication of the media. However, unlike traditional media, which is a communication between a socially fixed sender and an undecided addressee of speech, computer discourse enables individuals to communicate. The Internet is a combined way of presenting information to an audience. At the same time, various channels of transmission affect the content of the message transmitted, as well as the process of perception of information by the audience.

Power relations are an important component of the discursive context as a situation of communication, which includes "conditions of communication, subject line, time and place of communication, the communicators themselves, their relationship to each other."

Corporate discourse is a kind of institutional discourse, which is a purposeful communicative action that is implemented in the institutional sphere and manifests itself in interpersonal relationships within the given framework of status-role relations.

For the modern linguistic paradigm, it is significant to study the problem of achieving efficiency, the effectiveness of communication,

which is the subject of the theory of speech action. Achieving the effectiveness of communication is possible only with the adequate use of verbal and nonverbal components of communication. In this work, non-verbal components of communication are understood as prosodic, kinesic, and proxemic means used to convey information, organize interaction, form an image, think about a partner, influence another person.

The primary rules of the dispute are:

- non-interference of the teacher without the need for a dispute;

- constructive criticism;

- tolerance and tact of participants;

- the idea, phenomenon, or subject of discussion should be described exhaustively, systematically (in all aspects), and;

- essential statements should be systematized and generalized.

Dispute structure:

1. Definition of the idea, opinion, subject of discussion.

2. Announcement of the rules of the dispute. Discussion.

Systematization and generalization of the statement.

Summary. Reflection (EduDirect, 2021).

However, the debate on the Internet has several features.

Consider the example of mass media debate on the Internet. For example, one of the main tasks of mass media discourse is to meet the needs of society in the systematic assimilation of factual social context, depiction of current social reality, receiving, processing, and transmitting information to a wide audience, ensuring mass, orderly, regular and periodic dissemination of socially significant information. Types of media discourse are directly related to the genrefunctional features of the media space (Table 1).

Table 1.

Types of mass media discourse according to performed communicative function and Implementation channel. Data provided by Shevlyakova (2013).

\begin{tabular}{ll}
\hline Performed communicative function: & Implementation channel: \\
\hline a) journalistic discourse; & a) tele-discourse; \\
b) advertising discourse, and; & b) radio discourse, and; \\
c) PR discourse. & c) computer discourse. \\
\hline
\end{tabular}


At the crossroads of mass media and computer discourses, a new type of discourse was formed the Internet media discourse. Concerning traditional media, Internet media have the following advantages:

- Multimedia. The Internet allows you to combine visual, audio, print, and video components of different types of media;

- Personalization. Each of the Internet users can find information that interests him, information about any area of interest and human existence;

Interactivity. The Internet provides dialogue, interaction, feedback between Internet users, unlike traditional media;

Lack of intermediaries. Anyone with access to a computer and the Internet can publish information without hindrance, without interference or manipulation.

Comparing traditional media and online media, which emerged at the crossroads of media and computer discourses, we highlighted the following advantages of online media such as multimedia, personalization, interactivity, and the absence of intermediaries.

\section{Conclusions}

As a result of the study, the following conclusions were made.

1. Discourse on the Internet has such properties as an electronic signal of communication; virtuality; spatial and temporal distance; combining letter, image-visual, and imageauditory components; status equality of communicators; use of "smilies" to convey feelings, emotions; combining different types of discourse; adherence to computer ethics (netiquette). In turn, the central features of mass media discourse are the mass audience; thematic diversity; efficiency in obtaining mass information and its dissemination; availability of information.

2. The greatest influence on the linguistic features of the Internet dispute is the technological factor, and communication, being conceptually oral, is realized in writing, resulting in a new type of oral discourse with specific features at all levels of the language system.

3. Given the transition to numeral communication techniques, it should be emphasized that linguistic intelligence via Internet will increase (in direct proportion to this process).
Regarding further research, it is influential to examine the features of Internet linguistics in the context of political debate and to identify sustainable tactics of anti-crisis communication.

\section{Bibliographic references}

Akhrenova, N. A. (2009). Internet discourse as a global intercultural phenomenon and its linguistic design. Moscow: Publishing house of MGOU. Recovered from https://www.twirpx.com/file/540250/

Aleksandrova, O.V. (2003). The language of the mass media as part of the collective space of society. Moscow: Publishing house of Moscow State University. Recovered from http://evartist.narod.ru/text12/07.htm

Anderson, K.E. (2020). Getting acquainted with social networks and apps: it is time to talk about TikTok. Library Hi Tech News, 4(37), 7-12. Recovered from https://doi.org/10.1108/LHTN-01-20200001

Dobrosklonskaya, T.G. (2005). The role of the media in the dynamics of language processes. Bulletin of Moscow State University, 19(3), 38-68. Recovered from https://cyberleninka.ru/article/n/rol-smi-vdinamike-yazykovyh-protsessov

EduDirect. (2021). Dispute technology. Recovered from http://www.edudirect.net/sopids-952-1.html

Galichkina, E. N. (2001). Specificity of computer discourse in English and Russian: based on the genre of computer conferences (doctoral thesis). Astrakhan State Pedagogical University, Astrakhan. Recovered from https://www.twirpx.com/file/1268175/

Husar, M.V. (2004). Linguocognitive and communicative-pragmatic aspects of private newspaper advertisements (doctoral thesis). Kyiv National Linguistic University, Kyiv. Recovered from http://irbis-nbuv.gov.ua/cgibin/irbis_nbuv/cgiirbis_64.exe?C21COM=S $\& \mathrm{I} 21 \mathrm{DBN}=\mathrm{EC} \& \mathrm{P} 21 \mathrm{DBN}=\mathrm{EC} \& \mathrm{~S} 21 \mathrm{FMT}=\mathrm{f}$ ullwebr\&S21ALL=\%28\%3C.\%3EA\%3DГу cap\%20M\$\%3C.\%3E\%29\&Z21ID=\&S21S $\mathrm{RW}=\mathrm{GOD} \& \mathrm{~S} 21 \mathrm{SRD}=\mathrm{UP} \& \mathrm{~S} 21 \mathrm{STN}=1 \& \mathrm{~S} 2$ $1 \mathrm{REF}=10 \& \mathrm{~S} 21 \mathrm{CNR}=20 \& \mathrm{R} 21 \mathrm{DBN}=1 \& \mathrm{R} 21$ $\mathrm{DBN}=2$

Ilchenko, V.I. (2003). Expression of name in the media. Kyiv: Institute of Journalism. Recovered from http://irbis-nbuv.gov.ua/cgibin/irbis_nbuv/cgiirbis_64.exe?Z21ID=\&I21 $\mathrm{DBN}=\mathrm{ARD} \& \mathrm{P} 21 \mathrm{DBN}=\mathrm{ARD} \& \mathrm{~S} 21 \mathrm{STN}=1 \&$ $\mathrm{S} 21 \mathrm{REF}=10 \& \mathrm{~S} 21 \mathrm{FMT}=$ fullwebr\&C21COM $=\mathrm{S} \& \mathrm{~S} 21 \mathrm{CNR}=20 \& \mathrm{~S} 21 \mathrm{P} 01=0 \& \mathrm{~S} 21 \mathrm{P} 02=0 \&$ $\mathrm{S} 21 \mathrm{P} 03=\mathrm{A}=\& \mathrm{~S} 21 \mathrm{COLORTERMS}=1 \& \mathrm{~S} 21 \mathrm{~S}$ TR=Ільченко \%20B.I.\$ 


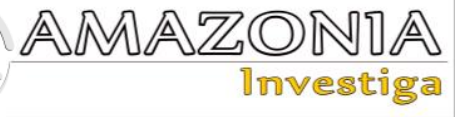

Kalmykov, A. A. (2005). Internet journalism. Moscow: Unity-dana. Recovered from http://www.ipk.ru/ftpgetfile.php?id=276

Khalyapina, L. P. (2005). Internet communication and teaching foreign languages. Kemerevo: Kuzbassvuzizdat. Recovered from https://cyberleninka.ru/article/n/2006-04015-halyapina-l-p-internet-kommunikatsiyai-obuchenie-inostrannym-yazykamkemerovo-2005-210-s

Kibrik, A.A. (2009). Modus, genre and other parameters of the classification of discourses. [PDF file] Recovered from https://ilingran.ru/kibrik/Discourse_classification@VJa 2009.pdf

Kozhemyakin, E. (2016). Discourse Analysis in the Digital Age: Empowering. New Literary Review, 2(138), 330-337. Recovered from http://www.intelros.ru/readroom/nlo/1382016/30038-diskurs-analiz-v-cifrovuyuepohu-rasshirenie-vozmozhnostey-rec-nakn-discourse-and-digital-practices-doingdiscourse-analysis-in-the-digital-era-1-ny2015.html

Kozhemyakin, E.A. (2010). Mass communication and media discourse: towards research methodology. Scientific bulletin of Belgorod State University. Series: Humanities, 12(83), 13-21. Recovered from https://cyberleninka.ru/article/n/massovayakommunikatsiya-i-mediadiskurs-kmetodologii-issledovaniya

Pastukhov, A.G. (2008). Media texts in discourse communities. Moscow: MAX Press.

Perhach, R.Y., \& Smirnova, A. (2019). Language means of manipulation in the press: content analysis. Young scientist, 10(74), 186-189. Recovered from https://doi.org/10.32839/2304-5809/201910-74-43

Ruda, O.G. (2021). Language means of youth agitation in the 2019 presidential election in Ukraine. Ukrainian Language Magazine, 1(77), 17-31. https://ukrmova.iulnasu.org.ua/vypusky-zhurnalu/20212/zhurnal-ukrayinska-mova-1-772021/movni-zasoby-agitatsiyi-molodi-navyborah-prezydenta-ukrayiny-2019roku.html

Shevlyakova, Yu.O. (2013). Features of Internet media discourse (based on English-language online magazines for adolescents). Scientific blog, 1, 1-6. Recovered from https://naub.oa.edu.ua/2013/osoblyvostidyskursu-internet-zmi-na-materialianhlomovnyh-on-lajn-zhurnaliv-dlyapidlitkiv/

Volodina, M.N. (2005). Mass media as a form of "public dialogue". Moscow: Publishing house of MGOU. Recovered from https://istina.msu.ru/publications/article/444 0784/

Zavgordnya, L.V. (2003) Stereotypes of generation and perception of journalistic work (doctoral thesis). Kyiv National Linguistic University, Kyiv. Recovered from http://www.irbis-nbuv.gov.ua/cgibin/irbis_nbuv/cgiirbis_64.exe?C21COM=2 $\& I 21 \mathrm{DBN}=\mathrm{ARD} \& \mathrm{P} 21 \mathrm{DBN}=\mathrm{ARD} \& Z 21 \mathrm{ID}=$ \&Image_file_name=DOC/2003/03zlvmgt.zi p\&IMAGE_FILE_DOWNLOAD $=1$

Zheltukhina, M.R. (2003). Tropological suggestiveness of mass-medial discourse: on the problem of the speech influence of tropes in the language of the media. Moscow: Institute of Linguistics RAS. Recovered from https://www.philol.msu.ru/ slavphil/books/j sk_25_16krasnych.pdf 